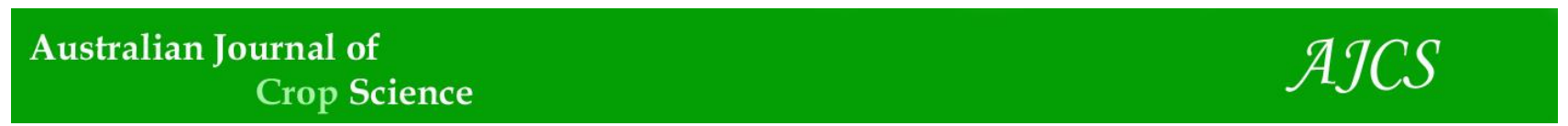

AJCS 15(10):1217-1223 (2021)

ISSN:1835-2707

doi: 10.21475/ajcs.21.15.10.p2497

\title{
Impact of ryegrass cover on lowland rice establishment
}

\author{
Marcos Belinazzo Tomazetti ${ }^{1 *}$, Edinalvo Rabaioli Camargo ${ }^{1}$, João Paulo Sousa Gomes ${ }^{1}$, José Maria Barbat \\ Parfitt $^{2}$, Jaqueline Trombetta da Silva², Ivana Santos Moisinho², Harriet Brickhill ${ }^{3}$, Germani Concenço ${ }^{2}$ \\ ${ }^{1}$ Department of Plant Protection, Federal University of Pelotas, Pelotas, Brazil \\ ${ }^{2}$ Brazilian Agricultural Research Corporation - EMBRAPA, EMBRAPA Clima Temperado, Pelotas, Brazil \\ ${ }^{3}$ Rice Extension, Leeton, Australia
}

*Correspondence: marcosbelinazzotomazetti@gmail.com

\begin{abstract}
This study aimed to analyze the impact of ryegrass as a soil cover on soil moisture level, initial rice establishment, grain yield and weed control in irrigated rice planted after ryegrass. The experiment was conducted under field conditions in randomized blocks design with four replications. Ryegrass (cv. BRS-Ponteio) was planted in autumn and glyphosate was used as a knockdown before rice planting. Ryegrass plants were cut at $0,0.15,0.30$ or $0.45 \mathrm{~m}$ above ground, resulting in different mulching levels. Rice (cv. Irga-424-CL) was planted in spring and was managed according to local crop recommendations. Although positive to the overall cropping system, ryegrass mulching suppressed rice emergence, especially with ryegrass cutting heights above $0.30 \mathrm{~m}$, thus increased seeding densities in rice fields with substantial ryegrass soil cover may be needed. Ryegrass mulching had no significant effect on weed suppression, with positive results being observed only with $\geq 3000 \mathrm{~kg} \mathrm{ha}^{-1}$ of ryegrass dry mass mulching. However, the rice yield in relation to the bare soil treatment was $14.3 \%$ less when straw quantity was $4500 \mathrm{~kg} \mathrm{ha}^{-1}$, reinforcing the need for evaluating the benefits and costs of ryegrass as a cover crop in rice production.
\end{abstract}

Keywords: No tillage; ryegrass straw; weed suppression.

\section{Introduction}

Rio Grande do Sul is the largest Brazilian rice (Oryza sativa) producer State, accounting for about $70 \%$ of the total production, followed by Santa Catarina with approximately $10 \%$ of the total national volume. These two states are considered stabilizers of the Brazilian market (Sosbai, 2016). In Rio Grande do Sul, the predominant planting system has minimal soil disturbance close to sowing (which includes systems with tillage in autumn as well as no-till systems). This system occurs in approximately $60 \%$ of the rice growing area, followed by conventional tillage $(30 \%)$ and pregerminated (less than 10\%) (SOSBAI, 2016).

In the rice regions of the State such as the Central Depression and Internal and External Coastal Plains, irrigated rice is grown annually without the use of soil cover plants. In the regions of the Western Border, Campanha and Southern Zone, rice is integrated in a system with extensive beef cattle production. In this system, rice and native pastures are grown in periods of two, three or more years (Correia et al., 2013).

However, the successive cultivation of rice in the same areas can reduce grain yield (Nie et al., 2007) and select weeds resistant to herbicides used in rice (SOSBAl, 2016), compromising crop sustainability and productivity (Jesus et al., 2007). Thus, one of the main strategies used to optimize the productive potential of the areas, whether at high or low fertility, is the use of crop rotation and succession systems. Systems that integrate different crops in the same area improve organic matter and soil nutrition in the medium and long term, due to the decomposition of residues and nutrient cycling (Prasad et al., 2016).

Lowland areas present limitations to the implantation of rotation systems and crop succession, mainly due to the poor drainage that limits plant development and grain yield of upland crops when planted in lowlands. Thus, due to the adaptability to poorly drained environments, the main winter cover crop used in irrigated rice cultivation is ryegrass (Lolium multiflorum). Poor drainage in the lowland areas limits plant development and grain yield of upland crops. Ryegrass (Lolium multiflorum) is adapted to poorly drained environments, therefore it is the main winter cover crop used in rotation with irrigated rice (Ferreira et al., 2015). This species presents low seed establishment price, ability to recycle part of the residual nitrogen, tolerance to cold and diseases and helps suppress weeds (Reddy, 2001). In addition to soil cover, ryegrass is one of the main winter pastures used in succession to irrigated rice (Bundt et al., 2015).

In lowland areas, the greater water retention into soil can delay rice sowing time by preventing the entry of sowing machines at the right moment. However, the undesirable effect of excess moisture at sowing can be mitigated by early (Autumn) soil preparation, adequate growing area (such as land leveling) and adjustment in dry mass of the cover crops at seeding time. 
On the other hand, the heavy addition of residues and the high carbon/nitrogen $(C: N)$ ratio of ryegrass biomass can cause immobilization of nitrogen by soil microorganisms, resulting in its unavailability in the initial stages of development of irrigated rice after ryegrass (Correia et al., 2013). Depending on the straw quantity, cover crops can also decrease water absorption by seeds due to reduced seed-soil contact. Thus, reduction in plant density and consequently grain yield, may be observed if rice when sown over high straw quantity.

The effectiveness and extensiveness of weed suppression by ryegrass straw is unknown since the straw quantity that allows weed control may be harmful to the rice plants. Barnyard grass (Echinochloa sp.) is one of the main weeds in irrigated rice around the world and is a positive photoblastic species (Bajwa et al., 2015). Therefore, shading provided by ryegrass straw on the soil can affect barnyard grass emergence.

Thus, the adjustment of ryegrass straw quantity is a fundamental factor for rice production in Rio Grande do Sul State. It is hypothesized that elevated ryegrass soil cover can harm rice establishment, even though it may suppress the barnyard grass emergence. Therefore, the objective of this study was to analyze the impact of soil cover with different ryegrass straw quantities on soil moisture, initial rice establishment, grain yield and barnyard grass control in irrigated rice sowed in its succession.

\section{Results}

\section{Soil water tension}

Soil water tension was higher in uncovered soil $(0 \mathrm{~m}$ cutting, no ryegrass) (Figure 1). About eight days before planting, some days with no rains caused the control treatment (no ryegrass) to reach water tension of about $110 \mathrm{kPa}$, while the higher cutting height reached only about $38 \mathrm{kPa}$. About 25 - 30 days after emergence (DAE), when an extended period with no significant rains was reported, similar behavior was observed where the control plot reached about $160 \mathrm{kPa}$ while the higher cutting height reached approximately $120 \mathrm{kPa}$ (Figure 1).

\section{Rice development}

Soil mulching negatively affected rice emergence levels (Figure 2). There was no treatment difference until about 9 days after seeding (DAS), but from that date onwards, soilmulching superior to $1500 \mathrm{~kg} \mathrm{ha}^{-1}$ of dry mass reduced rice plant density (Figure 2). In fact, not only was a delay in emergence reported, but treatments with $0.30 \mathrm{~m}$ or $0.45 \mathrm{~m}$ cutting heights were not able to reach similar plant densities as observed in the control plot.

The stabilization in rice plant density increase was reached about 20 DAS (Figure 2), where about 150 - 220, 127 - 174, $86-110$ and $50-79$ plants $\mathrm{m}^{-2}$ were observed respectively for $0,0.15,0.30$ and $0.45 \mathrm{~m}$ cutting heights. This difference was not recovered before the onset of the permanent irrigation by flooding. According to the $5 \%$ confidence intervals, between 120 and 170 plants $\mathrm{m}^{-2}$ were reported for $0-0.15 \mathrm{~m}$ cutting heights, compared to $50-100$ plants $\mathrm{m}^{-2}$ for $0.3-0.45 \mathrm{~m}$ cutting heights, 20 DAS (Figure 2).

Plants that were able to emerge under the ryegrass mulching, however, were able to grow with no considerable barriers. There was only a discrete effect of soil mulching levels on rice plant height (Figure 3). The greatest difference in rice plant height was observed about 15 DAS (the day considered as average for emergence), where plants at the
$45 \mathrm{~cm}$ cutting height of ryegrass were about 10 - 20\% lower than the reported for the other treatments (Figure 3).

There was no effect of soil mulching levels on rice dry mass (Figure 4). On average, each rice plant weighed about 60 - 78g 33 DAS / 18 DAE. Rice yield was affected by ryegrass straw quantity. There was no difference in yield up $3000 \mathrm{~kg} \mathrm{ha}^{-1}$ of ryegrass straw, but yield decreased $14.3 \%$ in relation to bare soil when straw quantity reached $4500 \mathrm{~kg} \mathrm{ha}^{-1}$ (Table 1).

\section{Weeds dynamics}

Barnyard grass was the predominant weed throughout the experiment, reaching a maximum density of about 1250 plants $\mathrm{m}^{-2}$ (Figure 5). Considering the natural occurrence of this weed, there is no effect of ryegrass cutting height on its occurrence.

\section{Discussion}

Soil water tension fluctuations, as function of the environmental conditions, depended greatly on the ryegrass cutting height (Figure 1), where the uncovered soil $10 \mathrm{~m}$ cutting, no ryegrass) resulted in a higher water tension in soil when rains were not frequent. No ryegrass cover allowed soil to dry more rapidly, while the higher cutting height prevented soil water evaporation. Irrigation recommendations state that rice should be irrigated back to saturation when the soil water tension is about $20-30 \mathrm{kPa}$ (Parfitt et al., 2017 a,b). Thus, ryegrass soil cover can help rice plant maintenance until rain or an irrigation occurs.

Straw deposited on the soil surface potentially attenuates water evaporation from soil. Mulching with $4000 \mathrm{~kg} \mathrm{ha}^{-1}$ (approximately equivalent to that obtained with $0.45 \mathrm{~m}$ cutting height in the present work) decreases cumulative evaporation up to $40 \%$ compared to bare soil (Mahdavi et al.,). Interestingly, soil water tension increased on slower rates as the soil was submitted to mulching, with about five days of difference for reaching the maximum water tension in soil when the control plot was compared to $0.45 \mathrm{~m}$ cutting height (Figure 1). Theoretically, this would allow five extra days for rice before reaching significant water stress levels, compared to fields with no soil mulching. This is particularly important for rice fields grown under alternative irrigation schedules and/or methods, as intermittent or sprinkler irrigation (Parfitt et al., 2017b).

While soil mulching is important for keeping adequate soil moisture levels as depicted in Figure 1, it also provided adverse rice establishment (Figure 2). High amounts of straw on the soil surface makes it difficult to lose soil moisture, which added to the low drainage characteristic of floodplain soils may ultimately reflect in reduced yield of rice grains, number per panicles and number of grains per panicle (Swarowsky et al., 2004), due to poor crop initial establishment.

The differences in rice plant density between mulching levels are not recovered even after 20 DAS (Figure 2). According to Ferreira et al. (2015), an early knockdown of ryegrass will reduce the $\mathrm{C}: \mathrm{N}$ ratio which increases the rate of decomposition of the residues, besides providing a greater area exposed for action of soil microorganisms. Thus, where a knockdown was carried out 15 days before sowing, rice plant density was the lowest since there was a greater amount of ryegrass straw remaining on soil surface. However, these treatments had a higher number of stems per plant which may be related to compensation occurring 
Table 1. Rice grain yield as a function of ryegrass straw quantity on the soil. Capão do Leão, RS, 2017.

\begin{tabular}{ll}
\hline Straw quantity $\left(\mathrm{kg} \mathrm{ha}^{-1}\right)$ & Rice yield $\left(\mathrm{kg} \mathrm{ha}^{-1}\right)$ \\
\hline 0 & $10190 \mathrm{~A}^{1,2}$ \\
1500 & $9529 \mathrm{AB}$ \\
3000 & $9226 \mathrm{AB}$ \\
4500 & $8736 \mathrm{~B}$ \\
\hline 1means followed by the same letter do not differ from each other by the Tukey's test $(\mathrm{p} \leq 0.05)$.
\end{tabular}

${ }^{1}$ means followed by the same letter do not differ from each other by the Tukey's test $(p \leq 0.05)$.

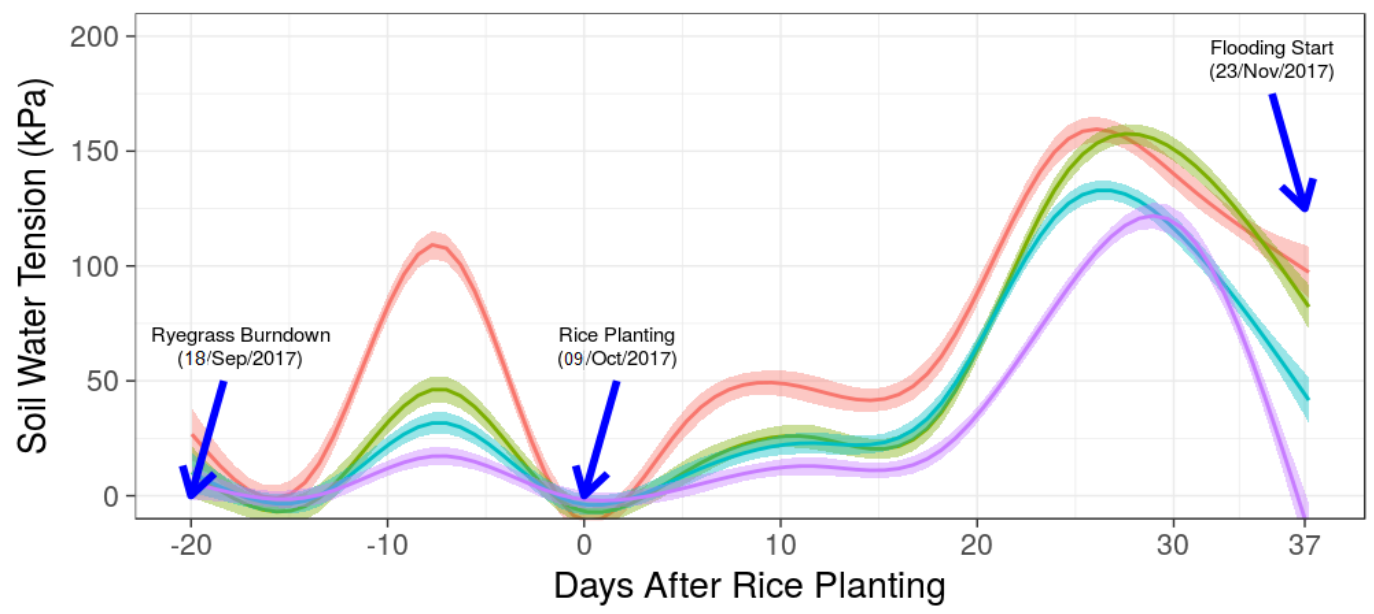

Cut_Height $=0=15-30=45$

Figure 1. Soil water tension fluctuation ( $\mathrm{kPa}$ ) from the ryegrass knockdown onwards, as function of treatment (different cover crop cutting heights). Capão do Leão, RS, 2017.

Table 2. Precipitation in the period of rice development. Capão do Leão, RS, 2017.

\begin{tabular}{ll}
\hline Date $(\mathrm{DAS})^{1}$ & Precipitation $(\mathrm{mm})$ \\
\hline 1 to 6 & 126 \\
10 & 62 \\
18 & 46 \\
38 & 16 \\
55 & 9 \\
62 & 7 \\
85 & 25 \\
98 & 26 \\
101 & 10 \\
107 & 19 \\
123 & 30 \\
135 & 9 \\
141 & 20 \\
\hline Total & 405 \\
\hline 1DAS: days after rice sowing (09 Oct. 2017).
\end{tabular}

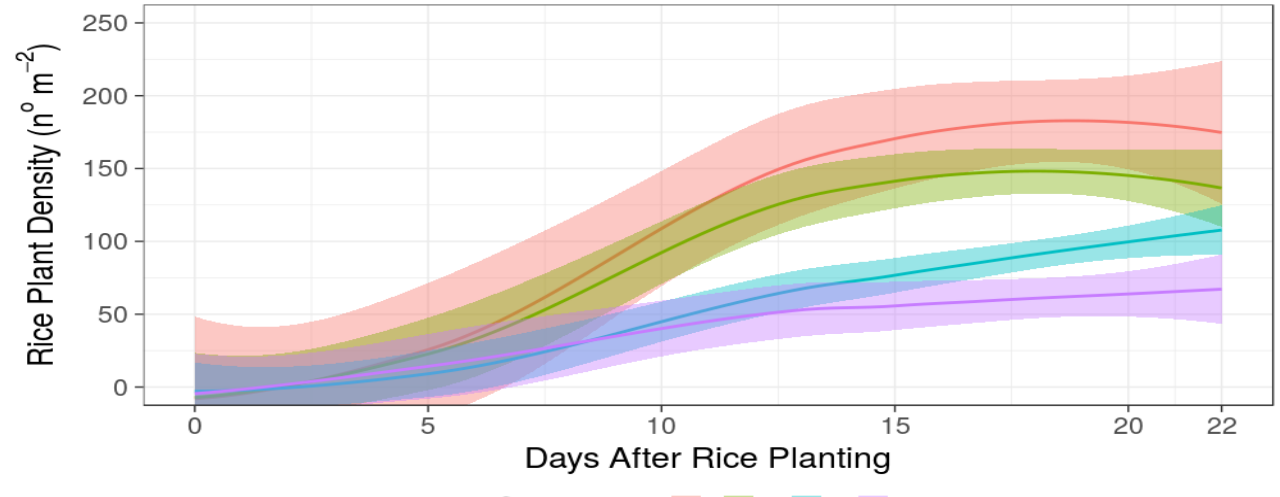

Cut_Height $=0-15=30=45$

Figure 2. Rice plant density ( $\left.\mathrm{n}-\mathrm{m}^{-2}\right)$ in days after sowing (DAS) as a function of treatment (ryegrass cutting height $\left.(\mathrm{cm})\right)$. Capão do Leão, RS, 2017. 


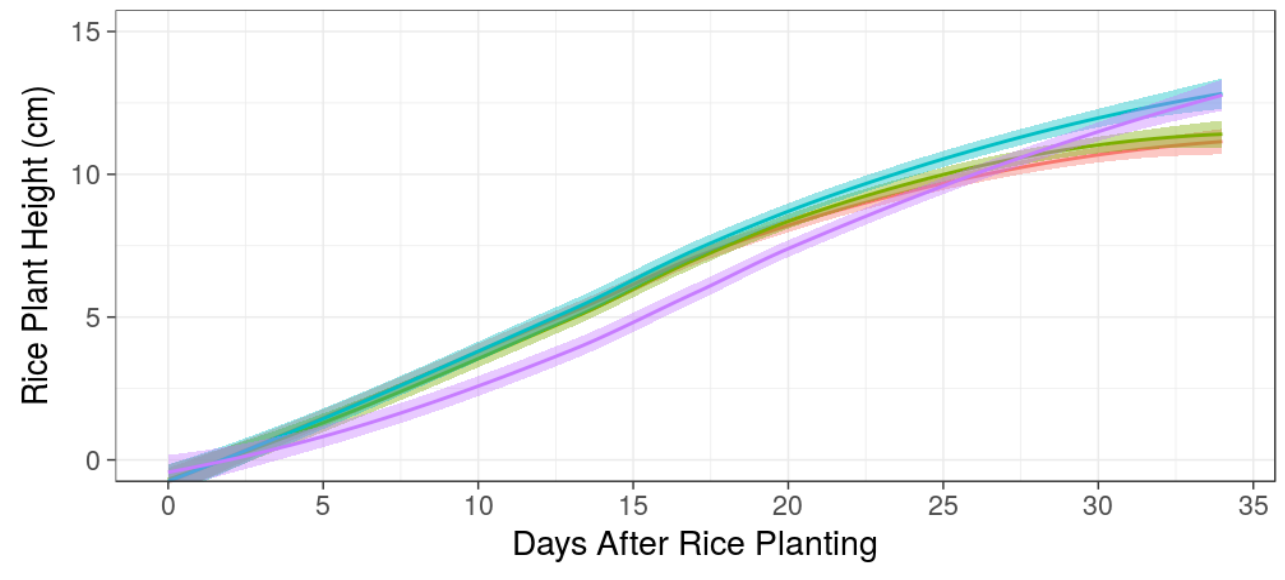

Cut_Height $=0-15-30=45$

Figure 3. Rice plant height $(\mathrm{cm})$ in days after sowing (DAS) as a function of ryegrass cutting height $(\mathrm{cm})$. Capão do Leão, RS, 2017.

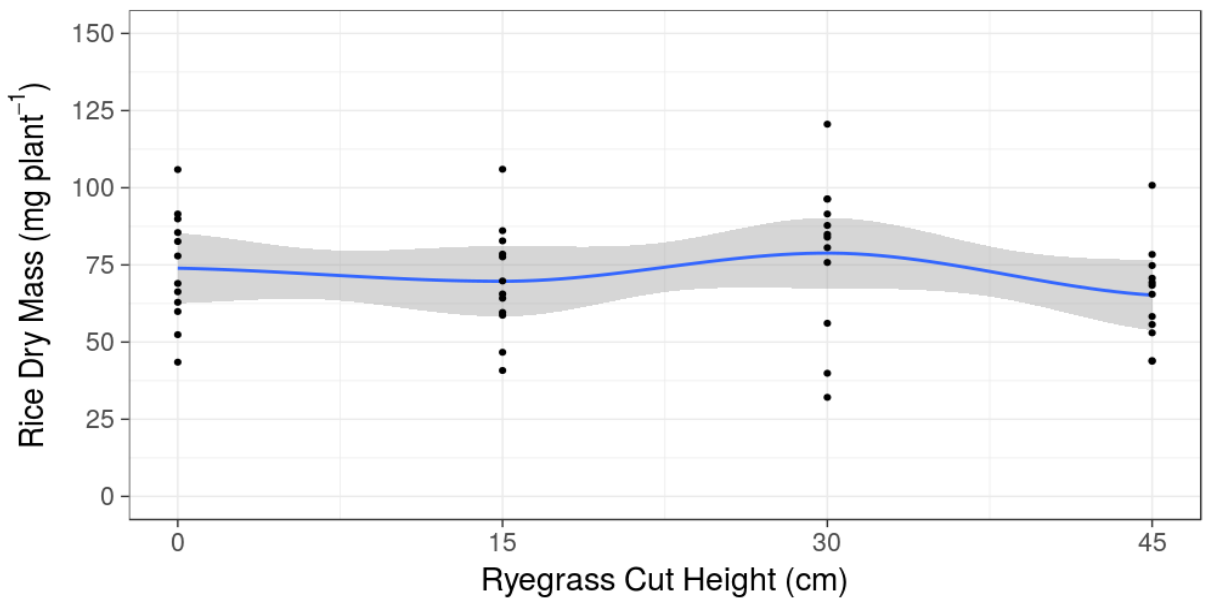

Figure 4. Rice plants dry mass (mg plant $\left.{ }^{-1}\right)$ as a function of ryegrass cutting height $(\mathrm{cm})$. Capão do Leão, RS, 2017.

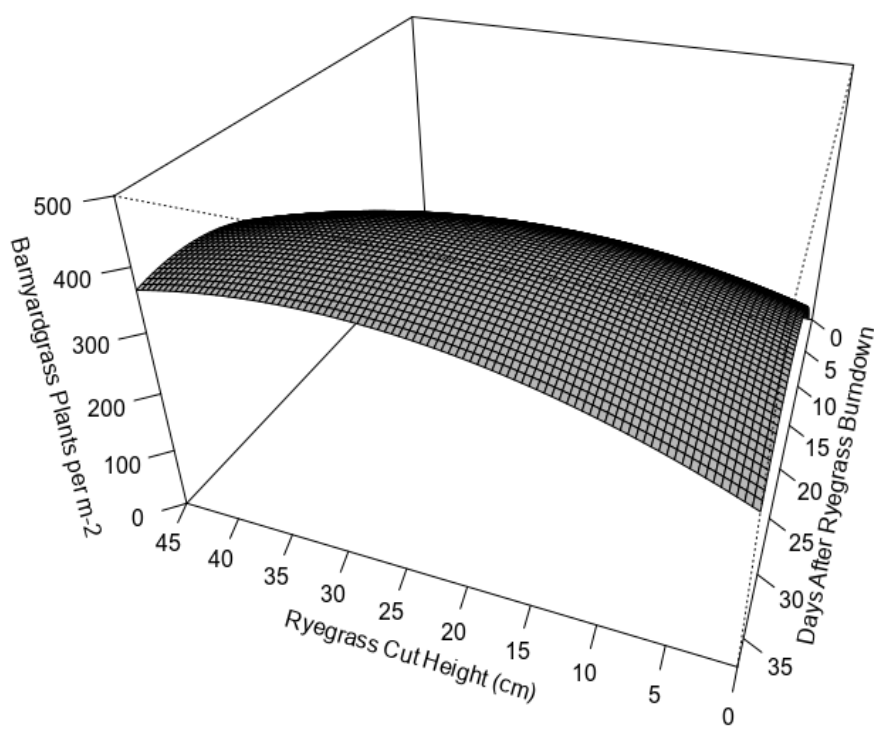

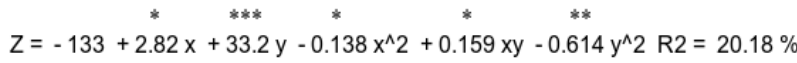

Figure 5. Barnyard grass density ( $\left.n \circ \mathrm{m}^{-2}\right)$ in the different ryegrass cutting heights after knockdown ( $\left.\mathrm{p} \leq 0.05\right)$. Barnyard grass occurrence increased consistently in days after knockdown, and no effect of ryegrass mulching was observed on weed suppression. Capão do Leão, RS, 2017. 


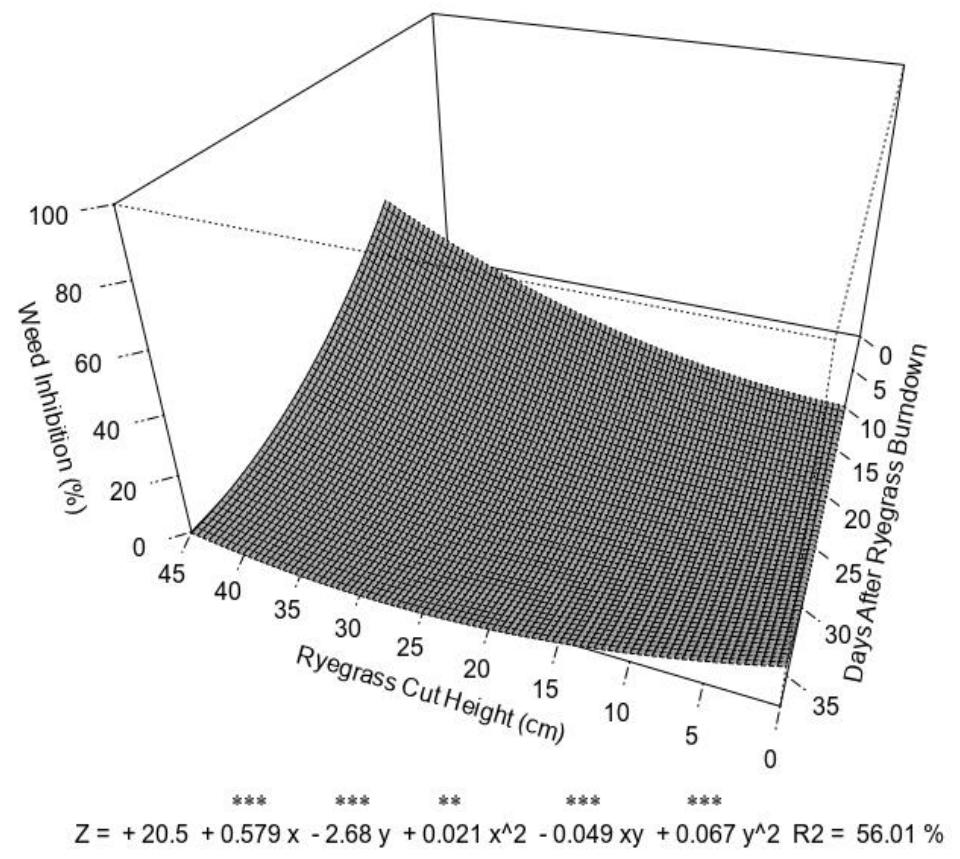

Figure 6. Weed inhibition (\%) in days after knockdown of different ryegrass cutting height $(p \leq 0.05)$. Little to no effect of ryegrass was noticed on weed suppression. Capão do Leão, RS, 2017.

in available space due to poor emergence (Prabha et al., 2011).

It was remarkable the delays and difference in plant emergence into the rows as function of both treatments and water excess. While some plants from a given row had emerged, other plants had emergence delayed by several days. There was no effect of ryegrass cutting levels on rice plant height (Figure 3 ), and similar results were obtained for rice dry mass (Figure 4). This result suggests that increased seeding rate can help solving the problem of reduced plant stand in rice cultivated on ryegrass areas.

Rice yield decreased when sown in the treatment with the largest straw quantity for several reasons. It is possible that nitrogen immobilization occurred, as nitrogen in rice leaves may be up to $11 \%$ less in rice over ryegrass straw than in conventional tillage (Ferreira et al., 2015). Also, rice yield cultivated over Brachiaria brizantha and B. ruziziensis was reduced $38,3 \%$ in relation to bare soil (Nascente, Crusciol, Cobucci, 2013), most probably for higher $\mathrm{N}$ immobilization. Furthermore, the seeds remained in colder conditions for longer time on the highest straw level, since the seeds were deposited at greater depth and straw above soil prevented solar radiation penetration. Thus, rice emergence was reduced.

Ryegrass seems to be inefficient in inhibiting barnyardgrass establishment for all cutting height ranges tested (Figure 5) as an average 200 - 250 seedlings $\mathrm{m}^{-2}$ of barnyard grass were observed in the treatments. Although apparently inefficient in suppressing barnyard grass, ryegrass was efficient in inhibiting the occurrence of the overall weed infestation (Figure 6), with a clear effect of both ryegrass cutting height and period after knockdown application. The efficiency of the knockdown with glyphosate was visible only in the first few days after application, as a severe re-infestation of the area with weed seedlings coming from the soil seed bank was noticeable about 10-20 days afterwards (Figure 6). Ryegrass mulching only helped in weed suppression when its cutting height was $\geq 0.3 \mathrm{~m}$, demonstrating that chemical control is important for successful weed control programs in rice.

\section{Materials and methods}

\section{Experimental location}

The experiment was carried out at the Federal University of Pelotas's Agricultural Center of Palma (CAP), in the municipality of Capão do Leão, RS, Brazil, geographic coordinates $31^{\circ} 48^{\prime} 22.3^{\prime \prime} \mathrm{S}$ and $52^{\circ} 28^{\prime} 56.8^{\prime \prime} \mathrm{W}$. The soil is classified as Typic Albaqualf in the North American classification ("Planossolo" in the Brazilian classification) (Embrapa-CNPS, 2006).

\section{Winter cover crop}

The experimental area was under fallow in the previous season and tillage was done with soil cultivated followed by plaining (soil levelling) with grader board prior to ryegrass establishment. Ryegrass cultivar BRS-Ponteio was planted at the density of $30 \mathrm{~kg} \mathrm{ha}^{-1}$ on 9 May 2017. The only fertilizer application was $90 \mathrm{~kg} \mathrm{ha}^{-1}$ of nitrogen, with $60 \mathrm{~kg}$ applied at tillering and $30 \mathrm{~kg}$ at culm elongation.

\section{Experimental design, treatments and assessments}

The experimental design used was randomized blocks with four replications. Treatments included four levels of ryegrass cutting heights $(0,0.15,0.30$ and $0.45 \mathrm{~m})$, which were closely equivalent to soil cover levels of $0,1500,3000$ and $4500 \mathrm{~kg} \mathrm{ha}^{-1}$ respectively. The variables assessed were: soil water tension, continuously monitored by automated data loggers; emergence; plant height and dry mass of rice; and density and suppression of barnyard grass (Echinochloa crusgalli), which was the main weed species present in the area.

In order to establish the relationship between ryegrass cutting height and the dry mass of the remaining straw prior to planting rice, ryegrass samples were collected in layers of 
$0.05 \mathrm{~m}$ in height from the tip of the canopy to the soil surface, at random points in the experimental area, to determine the dry mass that occurred from each height. The remaining mass was collected for subsequent dry mass determination (data not shown). The cutting in the respective treatments was done at the determined height by using orchard scissors and rulers. This was performed when ryegrass was at flowering.

\section{Ryegrass chemical desiccation / knockdown}

Ryegrass was knockdown with glyphosate using a dose of $1620 \mathrm{~g}_{\text {a.e. }} \mathrm{ha}^{-1}$ two-days after cutting (18 Sep. 2017) to establish the mulching. On 25 Sep. 2017, the soil moisture sensors (Watermark electro-tensiometers, Irrometer Co.) were installed, one per plot, at $0.05 \mathrm{~m}$ depth in order to monitor moisture in the $0-0.1 \mathrm{~m}$ soil layer. All sensors were connected to dataloggers that recorded soil water status every 60 minutes.

\section{Rice planting and management}

Rice was planted on 09 Oct. 2017, 21 days after the knockdown was applied. Plots measured $6 \mathrm{~m}$ long, with 11 rice rows spaced in $0.175 \mathrm{~m}$. The cultivar used was IRGA 424 RI at $90 \mathrm{~kg} \mathrm{ha}^{-1}$, using $335 \mathrm{~kg} \mathrm{ha}^{-1}$ of base fertilization $\mathrm{N}-\mathrm{P}_{2} \mathrm{O}_{5}-\mathrm{K}_{2} \mathrm{O}(05-20-20)$. Nitrogen topdressing was applied at two stages: $80 \mathrm{~kg} \mathrm{ha}^{-1}$ at $\mathrm{V}_{4}$ and $70 \mathrm{~kg} \mathrm{ha}^{-1}$ in $R_{0}$ (Counce et al., 2000). All other management practices were carried out according to the official technical recommendations for rice (SOSBAI, 2016).

Rice emergence occurred only on 24 Oct. 2017 due to heavy and successive rainfall events that occurred soon after sowing and flooded the area for some days (Table 2). Rice emergence and height were assessed in two $1 \mathrm{~m}$ samples randomly selected per plot. At each sampling point, rice emergence was counted and 5 rice plants had their height measured from the soil surface to the tip of the highest leaf. This was repeated two to three times a week until 20 days after the emergence (DAE).

\section{Rice long-term assessments}

Dry mass was measured twenty-eight DAE. Four samples per plot were collected, each sample consisting of 10 rice plants. The plants were packed in paper bags and placed into an oven with air circulating at $\pm 60 \circ C$ for three days. The rice grain yield was measured by manual harvest of five rice rows by $4 \mathrm{~m}$ of length. Yield was corrected to $13 \%$ of moisture and extrapolated to $\mathrm{kg} \mathrm{ha}^{-1}$.

\section{Weeds dynamics assessments}

Weekly evaluations of barnyard grass occurrence were performed, since it was the predominant weed in the experimental area. Barnyard grass was counted by randomly throwing metallic frames with dimensions of $0.25 \times 0.25 \mathrm{~m}$ within each treatment. Weed suppression was assessed by visually comparing plots with and without straw. Visual scores were attributed from 0 to 100 , where $0 \%$ meant the maximum emerged plants (no suppression) and $100 \%$ no plant emergence (total suppression). Permanent flooding irrigation for all treatments occurred on 23 Nov. 2017.

\section{Statistical analysis}

Statistical analysis were performed into the "R" environment (R CORE TEAM, 2016). In order to analyze the soil water stress, rice plant density, height and dry mass, $2^{\text {nd }}$ degree local regressions by the Loess method (Cleveland and Devlin, 1988) was fitted to the data sets, establishing the respective confidence intervals at $95 \%$ according to Cumming et al. (2007). The density of barnyard grass and its inhibition by the straw mulching were described by response surfaces as a function of ryegrass cutting height, and the days after knockdown, by adjusting $2^{\text {nd }}$ degree polynomial composite model, where $Z=a+b X+c Y+d X^{2}+e X Y+f Y^{2}$. Rice yield data was submitted to analysis of variance as function of ryegrass cutting height and, when means were significant, Tukey's test was applied. Significance level utilized was $\mathrm{p} \leq 0.05$.

\section{Conclusion}

The soil mulching supplied by ryegrass in rice fields planted in succession is essential for keeping adequate soil moisture levels in soil in cropping seasons with considerable drought periods. Although positive to the overall cropping system, ryegrass mulching suppresses rice emergence, especially with ryegrass cutting heights above $0.3 \mathrm{~m}$, and thus increased seeding densities in rice fields with substantial ryegrass mulching may be needed. Rice yield was reduced when ryegrass straw quantity was $4500 \mathrm{~kg} \mathrm{ha}^{-1}$. Little to no effect of ryegrass mulching was observed on weed suppression, with positive results being observed only with $4500 \mathrm{~kg} \mathrm{ha}^{-1}$ of ryegrass dry mass mulching. Therefore, for no tillage rice system, ryegrass straw quantity must be less than $3000 \mathrm{~kg} \mathrm{ha}^{-1}$ to not impair rice yield, and other control practices are needed for weed management, specifically for barnyard grass control.

\section{References}

Almeida WS, Panachuki E, Oliveira PTS, Menezes RS, Sobrinho TA, Carvalho DF (2018) Effect of soil tillage and vegetal cover on soil water infiltration. Soil Till Res. 175: 130-138.

Bundt ADC, Avila LA, Agostinetto D, Nohatto MA, Vargas HC (2015) Carryover of imazethapyr + imazapic on ryegrass and not-tolerant rice as affected by thickness of soil profile. Planta Daninha. 33: 357-364.

Cerdà A, González-Pelayo Ó, Giménez-Morera A, Jordán A, Pereira $P$, Novara $A$, Brevik EC, Prosdocimi $M$, Mahmoodabadi M, Keesstra S, Orenes FG, Ritsem CJ (2016) Use of barley straw residues to avoid high erosion and runoff rates on persimmon plantations in Eastern Spain under low frequency-high magnitude simulated rainfall events. Soil Res. 54: 154-165.

Cleveland W S, Devlin SJ (1999) Locally Weighted Regression: An Approach to Regression Analysis by Local Fitting. J Am Stat Ass. 83: 596-610.

Correia SL, Silva, PRF, Serpa MS, Vieira, VM, Boeni, M, Menezes (2013) Estratégias de manejo da palha de azevém para cultivo do arroz irrigado em sucessão. Rev Bras Ci Solo. 37: 512-520.

Counce PA, Keisling TC, Mitchell AJ (2000) A uniform, objectives, and adaptatives system for expressing rice development. Crop Sci. 40: 436-443.

Cumming G, Fidler F, Vaux DL (2007) Error bars in experimental biology. Journal of Cell Biol. 177: 7-11.

EMBRAPA - Centro Nacional de Pesquisa de Solos (CNPS) Sistema Brasileiro de Classificação de Solos. 2a ed. Rio de Janeiro, Embrapa Solos, 2006. 412p. 
Ferreira RB, Marchesan E, Coelho LL, Oliveira ML, Teló GM; Cargnelutti Filho A, Sartori GMS (2015) Manejo do azevém no estabelecimento inicial de plantas, na ciclagem de nutrientes e no rendimento de grãos do arroz irrigado. $\mathrm{Ci}$ Rural. 45: 2143-2149.

IRGA. Seção de Política Setorial. Dados de safra 2014/15 e 2015/16 - Sistemas de Cultivo. 2016.

Mahdavi SM, Neyshaboury MR, Fujimaki H, Heris AM (2017) Coupled heat and moisture transfer and evaporation in mulched soils. Catena. 151: 34-48.

Montenegro AAA, Abrantes JRCB, Lima JLMP, Singh VP, Santos TEM (2013) Impact of mulching on soil and water dynamics under intermittent simulated rainfall. Catena. 109: 139-149.

Parfitt JMB, Andres A, Concenço G, Teló GM, Schreiber F, Silva JT, Moisinho IS, Timm PA (2017a) Rice and Barnyardgrass: Water Stress and Initial Establishment. Am J Plant Sci. 8: 3110-3119.

Parfitt, JMB; Concenço G, Scivittaro WB, Andres A, Silva JT, Pinto MAB (2017b) Soil and Water Management for Sprinkler Irrigated Rice in Southern Brazil. In: Jin Quan Li. Advances in International Rice Research. 1st ed.: IntechOpen, pp. 3-18.

Prabha ACS, Thiyagarajan TM, Senthivelu M (2011) System of rice intensification principles on growth parameters, yield attributes and yields of rice (Oryza sativa L.). J Agron. 10: 27-33.

Prosdocimi $M$, Jordán A, Tarolli $P$, Keesstra S, Novara A, Cerdà A (2016) The immediate effectiveness of barley straw mulch in reducing soil erodibility and surface runoff generation in Mediterranean vineyards. Sci Total Env. 547: 323-330.
R Development Core Team. (2016) R: A language and environment for statistical computing. Vienna: $R$ Foundation for Statistical Computing. Available in: $<$ http://www.R-project.org/>.

Reddy KN (2001) Effects of cereal and legume cover crop residues on weeds, yield, and net return in soybean (Glycine max). Weed Technol. 15: 660-668.

SOSBAI - Sociedade Sul-Brasileira de Arroz Irrigado. Reunião Técnica da Cultura do Arroz Irrigado (31:2016: Bento Gonçalves, RS) Arroz irrigado: recomendações técnicas da pesquisa para o Sul do Brasil / Sociedade Sul- Brasileira de Arroz Irrigado. - Pelotas: SOSBAI, 2016. 200p.

Jesus RP, Corcioli G, Didonet AD, Borges JD, Moreira JAA, Silva NF (2007) Plantas de cobertura de solo e seus efeitos no desenvolvimento da cultura do arroz de terras altas em cultivo orgânico. Pesq Agrop Trop. 37: 214-220.

Silva MA, Silva MLN, Curi N, Avanzi JC, Leite FP (2001) Sistemas de manejo em plantios florestais de eucalipto e perdas de solo e água na região do Vale do Rio Doce, MG. Ci. Florest. 21: 765-776.

SOCIEDADE SUL-BRASILEIRA DE ARROZ IRRIGADO-SOSBAI. Arroz irrigado: Recomendações técnicas da pesquisa para o Sul do Brasil. Itajaí, SOSBAI, 2012. 179p.

Swarowsky A, Righes AA, Marchezan E, Rhoden AC, Gubiani El (2004). Manejo da palha de azevém, da adubação de base e da água de drenagem na produção de arroz irrigado. Ci Rural. 34: 393-397. 